\title{
The impact of corporate governance measures on the performance of West African IPO firms
}

\author{
Bruce Hearn* \\ University of Leicester
}

\begin{abstract}
This paper examines the impact on underpricing and firm market value arising from IPO firms implementing a range of governance attributes such as the separation of CEO and Chairman roles, the founder ceding CEO position, establishment of committees and board size. Furthermore I study the determinants of director retained ownership and the relation between this and underpricing. Using a comprehensive sample of 37 locally listed IPO firm's from across West Africa I find evidence of a mixed impact from the adoption of universally recognised governance mechanisms. Higher levels of retained director ownership increase underpricing in contrast to that of founders.
\end{abstract}

Keywords: IPO; Underpricing; Cost of Equity; West Africa; Agency Theory

* Corresponding author: School of Management, Ken-Edwards Building, University of Leicester, Leicester. UK. LE1 7RH. Tel: 44(0)116 252 5141. Email: bruce.hearn@1e.ac.uk 


\section{The impact of corporate governance measures on the performance of West African IPO firms}

\section{Introduction}

There is a now considerable body of literature focussing on the impact of corporate governance mechanisms on IPO (Initial Primary Offering) firm performance and underpricing. However much of this extent literature is devoted to the developed markets of US and Europe (see Gompers (1996) and Gompers et al (2008)) with a lesser, though significant amount, directed towards developing countries. There is little, if any, focussing on Sub Saharan Africa, and in particular West Africa which makes an especially interesting focus given considerable recent interest in these smaller frontier markets and their role in the promotion of sustainable domestic business finance and governance (Hearn and Piesse, 2010). Equally there is considerable emphasis in the more recent literature on the optimal role of firm level governance in the wake of the global 2008/2009 financial crisis and economic downturn and the role of institutions in facilitating optimal economic outcomes (Fosu et al. (2010); Kirkpatrick (2009); Claessens (2003)). The West African region's markets are characterised by a divisive split in accordance to legal and institutional development with markets such as the integrated Francophone regional exchange of BRVM (Cote d'Ivoire) ${ }^{1}$, Cameroon and Cape Verde Islands following a variant of French civil code law while Ghana and Nigeria adhere to English common law (La Porta et al (2008); Joireman (2001)). In particular, given the considerable recent interest in these markets as a source of sustainable development finance and in the attraction of foreign direct investment (FDI), there has been a significant focus on improvements to the regions governance at a firm level. Consequently I am motivated to ask whether there is a performance impact from IPO firms initiating improvements in corporate governance that are in line with those prevailing in developed OECD markets.

Study of the West African is motivated by countries within this region exhibiting sharp differences between civil code law institutions, imparted by former French or Portuguese colonial metropole, and their common law counterparts, derived from former British colonial rule (Joireman, 2001). Equally owing to extractive nature of industrial development across the region with a principal focus of agricultural or mining commodities government apparatus and supportive commercial legal institutions are narrow in focus in promoting the interests of powerful local social and political elites (Lavelle (2001); Hearn and Piesse (2009)). However civil code law regimes by design are particularly vulnerable in the protection of property rights owing to their promotion of centralised authority and property rights of the state in preference to those of individual minority interests (Hayek, 1960). Furthermore the emphasis of civil code legal regimes in following "bright

\footnotetext{
${ }^{1}$ The Francophone West African Economic and Monetary Union (also known Union Monétaire et Économique de l'Afrique de l'Ouest (UMEAO)) countries include Cote d'Ivoire, Benin, Togo, Burkina Faso, Mali, Niger, Senegal and Guinea-Bissau
} 
line rules" (Levine, 2005) passed into legislative law by lawmakers that largely relegate judiciary to an administration role creates further structural impediments to the financial and economic innovation and development across the region (Joireman, 2001). Furthermore a lack of supportive legal bureaucracy in civil code countries or a comprehensive body of supportive case law in common law countries at independence together with their has hindered the ongoing development and evolution of legal systems (Joireman, 2001) and enforced structural rigidities through the relative lack of property rights protection. As a consequence of these differences the region is characterised by marked differences between largely French civil code institutional development centred on relationship and network-based external finance and common law institutions emphasising markets-based development. A further consequence of the relative differences in development of markets as well as the emphasis placed on market-based economic reform by the international financial institutions that many of the region's economies have followed in structural reform programs is that listings are commonly made up from either larger former state owned enterprises (SOEs) or smaller family firms centred on a principal owner-founder entrepreneur. Consequently this provides a unique context to study the implicit effects of legal regime through its more indirect and pervasive influence on optimal governance mechanisms in the mitigation of informational asymmetry and protection of minority investor property rights.

The concept of underpricing in the flotation of new stock represents a direct wealth transfer from the founders and initial shareholders to new external investors (Filatotchev and Bishop, 2002) but its extent can be significantly influenced by the extent of protection of property rights over a financial security's entitlements to corporate cash flows, whether these are enshrined in the prevailing legal system (La Porta et al, 1998 henceforth LLSV), or through optimal corporate governance mechanisms (La Porta et al, 2000). However while La Porta et al (1997) first characterised differences in ownership concentration across countries with those of civil code as opposed to common law being dominated by insiders with less dispersion LLSV found evidence across a sample of 49 countries that property rights and minority investors were best protected in common law systems followed by Scandinavian and German civil codes and least in French civil systems. As such corporate governance is a set of mechanisms more concerned in the protection of outside investors from expropriation by corporate insiders (La Porta et al, 2000). This has a number of implications in the monitoring and surveillance of insiders with a unitary supervisory board structure composed of representatives of major shareholders being favoured in civil code countries where legal protection of property rights is weaker, incentives to expropriate outsiders higher, and participation of minority investors discouraged (Jensen and Meckling (1976); La Porta et al, 1999; 2000). Consequently governance practices such as split boards and separation of the roles of CEO and Chairman as well as more diversified ownership are not common in civil code law countries in contrast to their common law counterparts (La Porta et al, 2000). The civil code legal system engenders economic structural 
rigidities where internal and relationship-based forms of finance and associated corporate governance supersede external market-driven forms of finance and firm-governance structures of common law countries (Levine, 2005). The level of economic rigidity engendered by the legal institutions also infers that market-determined outcomes to firm governance are at best unlikely (Levine, 2005) with ownership structure being much less likely to adapt to pressures from investors searching for value gains as is the case in Germany (Kaserer and Moldenhauer, 2008). As a consequence of these structural rigidities and ownership characteristics Kaserer and Moldenhauer (2008) assert that the firm performance-ownership relationship is likely to be less susceptible to endogeneity than in common law countries with legal institutions promoting external finance and well developed financial markets.

The study of the performance effects arising from different corporate governance mechanisms such as the size of board of directors, itself a measure of the coordinative and communication ability of boards, instigation of board oversight audit, accounting and governance committees, separation of roles of Chief Executive Officer (CEO) and Chairman, and whether the founder retains control in holding position of CEO provides some detailed insight into the mitigation of asymmetric information between principals (owners) and agents (incumbent managers). Examination of firms undergoing IPOs is especially useful given this important milestone in the firm's life cycle since its corporate governance is likely to be clearer at listing owing to compliance with onerous regulation than at any other point in its history (Filatotchev and Wright, 2005). Much of corporate governance legislation and best practice guidelines emanates from developed OECD markets such as the UK's Cadbury Report, US Sarbanes-Oxley Act and South Africa's King II and III reports. This is largely explicitly focussed on the optimal division of roles and the enhanced communication between different entities in order to create a universally recognized set of standards that are adhered to by all parties (Jensen and Meckling (1976); Fama and Jensen (1983); Kalbers and Fogarty (1998)). However while this legislation has been generally adopted as best practice worldwide it's institutional origins are those of generally economically developed Western economies dominated by democratic institutions with a generally level political and legal institutions providing protection of property rights (Levine (2005); La Porta et al (2008)). These underlying assumptions concerning the social and political structure of the societal matrix in West African countries are at best tenuous given the prevalence of narrow political economies (Lavelle (2001); Hearn and Piesse (2009)) owing to their having inherited a narrow range of institutions from colonial metropoles that are geared to the engendering of political and social elites (Joireman $(2001,2005)$ ). However the civil code institutional environment engenders collaborative networks between firms due to the relative weakness in legal contract enforcement (Hoskisson et al, 2004) which fits effectively within the deeper West African societal institutional matrix, itself shaped by traditional values and affiliations. This in turn infers that the business environment is shaped largely by relationship or 
network based affiliations between investors, agents and market participants which mitigates transactions costs with only those larger better capitalized and internationally focussed firms able to comply with international corporate governance best practice as a way of attracting valuable foreign investment.

The previous literature regarding the impact of corporate governance mechanisms such as the retention of the founder as CEO, board size, establishment of independent committees and separation of roles of CEO and chairman have principally focussed on the signalling of quality arising from the implementation of these mechanisms to potential IPO investors. Firms where the founderentrepreneur retains a controlling role as CEO following an IPO are likely to be subject to greater scrutiny by investors given the high private benefits of control and questionable legal enforcement in markets characterised by weaker legal protection of property rights (Levine (2005); Brennan and Franks (1997)). This leads to higher agency costs as entrepreneur-founders are likely to be more reluctant to disclose proprietary information to potential IPO outside investors (Shane and Cable, 2002) while founders are also more likely to engage in opportunistic actions for personal gratification such as tunnelling at the expense of outside shareholders (Jensen and Meckling, 1976). One way to mitigate these issues is for founders to initiate costly governance mechanisms that would be too expensive to replicate in all but the highest quality firm's thereby effectively signalling quality to outside investors (Downes and Heinkel, 1982). One such mechanism is for founders to retain a significant portion of ownership (Leland and Pyle, 1997). A similar reasoning applies to director level retained ownership with directors themselves as corporate insiders being able to signal the quality of their firm through high levels of retained ownership. Consequently I conjecture that in line with previous findings in the literature (Bruton et al, 2009) that there is a curvilinear (U-shaped) relationship between underpricing and retained ownership by founders and directors. As such underpricing first decreases before subsequently increasing with rising ownership. However the continued presence of the founder as CEO following IPO will be perceived negatively by potential investors at IPO and as such I conjecture it will be positively related to higher levels of underpricing. The board of directors itself can be viewed as a tool that is useful in mitigating asymmetric information with larger boards being more dispersed and incurring greater coordination costs than smaller counterparts where communication is engendered. As such I conjecture that increases in board size will be positively related to increases in underpricing reflecting this asymmetric information cost from poorer coordination. Following this reasoning there is a considerable literature detailing the beneficial impact on the reduction of asymmetric information from formal separation of the roles of CEO and Chairman underlying the necessity of having a truly independent set of directors in a monitoring capacity able to challenge inefficient decisions by executive directors and incumbent management (Fama (1980); Fama and Jensen (1983); Shleifer and Vishny (1997)). Consequently I conjecture that separation of the roles of CEO and Chairman will lead to a reduction in underpricing, 
i.e. a negative relationship with asymmetric information. The creation and establishment of independent board committee's is an expensive process for many firms and while this can be seen as a form of signalling quality to potential outside investors (Downes and Heinkel, 1982) there is a lack of consensus in the literature regarding their beneficial impact over and above the oversight role undertaken by truly independent directors themselves (Anderson and Reeb (2004); Golden and Zajac (2001)). However despite the debate and subsequent lack of consensus in literature regarding the beneficial role of committees, and in particular board level audit committees, the highly relationshipbased business environment of West Africa (Lavelle, 2001) will likely exacerbate the findings of Turley et al (2004) who find that the formation and reliance of firms on independent audit committees actually cause net increases in agency and monitoring costs. However despite these concerns regarding the mixed evidence over the establishment and true level of independence of board committees I conjecture that the establishment of board committees as a governance device should have a negative relationship with underpricing in reducing asymmetric information.

These conjectures lead to the formulation of the following hypotheses with respect to the impact of governance measures on firm performance and the determinants of director and founder retained ownership. The relationship between increasing retained director ownership and underpricing should be curvilinear (U-shaped) (H1.2) while that for founder-entrepreneur retained ownership and underpricing is inverted curvilinear (inverted U-shaped) (H1.2). Levels of underpricing are positively associated with board size, founder ceding CEO position, and the separation of roles of CEO and Chairman and negatively associated with establishment of committees $(\mathrm{H} 2.2,2.4,2.6,2.8)$. Firm's market value is positively associated board size, establishment of committees, and negatively associated with founder ceding CEO role and separation of roles of CEO and Chairman (H2.1, 2.2, 2.5, 2.7). Firms that instigate separation of the roles of CEO and Chairman are less likely to have founder retaining CEO position while being more likely to have larger boards and higher levels of board independence (H3.1 to H3.3). Similarly firms establishing committees are less likely to be associated with founder retaining CEO position, more likely to be associated with larger boards and equally less likely to be associated with board independence (H3.4 to H3.6). Given the serious potential issues of CEO and insider dominance of board and the moral hazard arising a potential costly method for higher quality firms to signal their quality is for CEO and directors to retain ownership following IPO. As such CEO retained ownership should be negatively associated CEO equals Chairman and board size while being positively associated with establishment of committees and founder retaining CEO role (H4.1 to H4.4). Equally director ownership should be negatively associated with CEO equals Chairman while being positively associated with committee establishment, founder being CEO and board size (H4.5 to H4.8). However given concerns over managerial entrenchment and high private benefits of control prevail retained director ownership should be positively associated with underpricing (H4.9). 
I find evidence that only some of the standard governance measures are effective in reducing underpricing and mitigating asymmetric information. Notably separation of CEO-Chairman duality and founder ceding CEO position have a beneficial impact on underpricing while the increased coordination and communication issues associated with larger boards has a negative impact. The establishment of committees empowered with independent oversight of directors and incumbent management which is a cornerstone of international governance best practice actually has a detrimental impact on underpricing. Levels of CEO and director retained ownership are more determined on the basis of the separation of CEO and Chairman roles and the founder ceding CEO position, while retained director ownership has a detrimental impact from increasing underpricing. However there is some evidence that very high levels of retained ownership by founder-entrepreneurs leads to a decrease in underpricing which would infer a different optimal governance mechanism centred on their being corporate block-shareholders that are best placed to protect minority investor property rights in the absence of effective legal system.

This paper is structured as follows: The next section introduces the data while section 3 outlines the methodology in detailing the three respective dependent firm performance variables, namely firm value and underpricing as well as the hypotheses. Section 4 provides the empirical results while the final section concludes.

\section{Data}

\subsection{Sample}

Comprehensive lists of IPO's and listings were obtained direct from the national exchanges of Cape Verde Islands (Bolsa de Valores de Cabo Verde), Cameroon (Bourse de Douala), BRVM (Cote d'Ivoire), Ghana for the period 2000 to 2009. Nigerian lists were only available from 2002 to 2009. These were cross checked with national stock exchange websites and from similar lists obtained from major brokerage houses to ensure accuracy in the case of Nigeria. This resulted in a list of 100 listings having taken place across the region during the period 2000 to 2009. Flotation prospectuses were then hand-collected from the Ghana stock exchange and Bolsa de Valores de Cabo Verde (Cape Verde Islands exchange) and from the stock exchange website for the Bourse de Douala (Cameroon exchange) while the Thomson Corporation Perfect Information were used to source Nigerian prospectuses. This resulted in the procurement of 66 listing prospectuses amounting to all listings in Cape Verde, 4 out of 8 listings in BRVM, 16 out of 18 listings in Ghana, 1 out of 3 listings in Cameroon and finally 29 out of 67 listings in Nigeria.

I then exclude readmissions and transfers of listings between main and development boards while also excluding demergers, reorganizations and flotation of preferred stock, convertibles, unit and investment trusts. Consequently the list of valid IPO prospectuses was reduced to the current sample size of 37 IPO firms. These floated ordinary shares with single class voting rights. Share 
prices were obtained from Bloomberg, DataStream and direct from the national stock exchange in Cape Verde and Cameroon. US\$ Exchanges rates were obtained from Bloomberg. The classification of each market according to its legal origin was made using La Porta et al (2008).

\subsection{West African securities markets}

There are considerable differences between West Africa's stock markets with the greatest of these being between markets adhering to common as opposed to civil code commercial and regulatory law. However all markets are characterised by narrow political economies controlled by social and political elites (Lavelle (2001); Hearn and Piesse (2009)) and only a handful of brokerage firms and indigenous investment banks with minimal trading activity. The lack of an established domestic institutional investor community in many of the markets combined with poor infrastructure create further difficulties in attracting much needed foreign investment (Hearn and Piesse (2009)). An additional issue arises from trading activity occurring outside the formal exchanges with only the preagreed details being acknowledged during designated trading sessions as is the case in Ghana (Akotey, 2008).

The evidence in Table 1 detailing the sample structure reveals the more sporadic nature of listings across the region. Listings activity on the BRVM acting as the West African Francophone regional exchange is largely static during the sample period with notable exceptions being Onatel, the Burkina Faso telecommunications operator, two Bank of Africa affiliates from Niger and Benin, and a local Ivorienne firm. This regional focus to the listings on the otherwise inactive market (Lavelle, 2001) is largely the result of political pressure and a marketing drive designed to enhance the regional focus of the market (Hearn and Piesse, 2010). It is also facilitated in practice by the extended regional network of Société de Gestion et d'Intermediation (SGIs) in each member state of the Union Economique et Monétaire Ouest Africaine (UEMOA) who act as Chef de File (Lead Manager and underwriter) in flotations. The Cameroonian Bourse de Douala has been similarly inactive during its history since inception in 2003 and only attracted its first listings in 2008 (DSX website, 2010) while the Cape Verde Islands exchange has had greater success despite the very small size of the Islands economy in attracting four listings since its establishment in 2005 (BVC website, 2010). All three of the smaller illiquid civil code exchanges operate sophisticated electronic call auctions in order to achieve the greatest informational efficiency and have small brokerage communities dominated by the affiliate arms of major French, and Portuguese in case of Cape Verde, banks (Hearn and Piesse, 2010). There are substantially more IPOs in the case of the two common law markets, namely Ghana and Nigeria, although the majority of these firms notably have head office locations in the immediate vicinity of the exchange itself providing further indication of the narrow formal economy in each case. A greater proportion of IPOs in Ghana than in Nigeria are made up from privatizations of government and state agency ownership stakes in former state owned enterprises (SOEs) while the listing of 
Gambia's Trust Bank on the Ghanaian exchange is a rare example of politically motivated listing between smaller common law West African markets.

\section{Table 1}

\section{Methodology}

This study is focussed on the performance effects of IPO firms from a variety of corporate governance mechanisms, namely separation of roles of CEO and Chairman, establishment of independent committees, board size and retention of founder-entrepreneur as CEO. As such the first section details the effects of increases in founder-entrepreneur and director (insider) ownership and levels of underpricing. Subsequent sections then focus on the impact of various governance mechanisms on firm value, underpricing at both 2 weeks and 180 days. A final analysis is made of the determinants of IPO firms implementing the governance mechanisms of board committees and separating the roles of $\mathrm{CEO}$ and Chairman. A major consideration with such a small dataset of 37 IPO firms is the effect of small sample bias on the statistical inference of models used. Attempts to mitigate these concerns centre on the employment of panel OLS models that draw statistical strength from both time series and cross sectional elements as well as the use of a smaller number of independent variables in line with recommendations in Good and Hardin (2009). The reduction in the number of independent variables is even more important owing to the presence of missing data in some of the IPO firms causing a further reduction in sample size actually employed in models. Consequently the effects of small sample bias should be taken into consideration when interpreting the results.

\subsection{Firm value}

The measure of firm value used is the natural logarithm of the ratio of the market value of equity on the $14^{\text {th }}$ trading day (specifically the market price at the close of the fourteenth trading day multiplied by the total number of shares outstanding) and the firm's revenues at the IPO year. This is in line with Shenone (2004) and is similar to that employed in Purnanandam and Swaminathan (2003) where it is argued that measures such as Tobin's $\mathrm{Q}$ and common stock price multiples such as price-toearnings ratio and market-to-book value of equity, are noisy measures of firm value for IPOs. An additional issue regarding the use of stock price multiples is the common occurrence of negative values (Shenone, 2004) which the natural logarithm of the ratio of market value on $14^{\text {th }}$ day to revenues avoids. The metric can also be represented as:

$$
\text { Value }_{i}=\log \left(\frac{\text { Market Value at } 14 \text { th trading day }}{\operatorname{Re} \text { venues at IPO year }}\right)
$$




\subsection{Underpricing}

Initial returns are used as a measure of underpricing. Two variants are used, namely that in 2 weeks and then 180 days following listing on exchange. This is due to concerns over the severity of illiquidity in West Africa's equity markets causing price-rigidity (Smith (2005); Hearn and Piesse (2010)) that in turn would inhibit the movement of prices in relation to their ability to reflect order flow and information (O'Hara, 2003). In line with Filatotchev and Bishop (2002) underpricing is calculated as the difference between stock price at 2 weeks (or 180 days) and the issue price divided by the issue price:

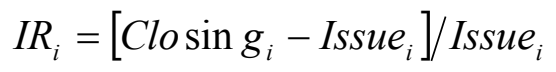

\subsection{Relationship between Director and Founder retained ownership and underpricing}

While an IPO as a single event in the corporate life cycle of firms represents a direct transfer of wealth from initial investors and entrepreneur-founders to outside investors (Daily et al (2003); Bruton et al (2009)) the founders and early stage investors ownership is usually determined by lockup agreements preventing sale of shares for a fixed period of time following the listing (Bruton et al, 2009). However there is evidence that large amounts of stock released after the IPO as covenants of the lock-up agreement are waived (Brav and Gompers, 2003) inferring that founders are particularly keen to retain ownership in high quality ventures. This is a particularly prevalent signal of quality given the founder-entrepreneur is foregoing opportunities to diversify his/her portfolio in order to retain significant levels of ownership in the firm (Jensen and Meckling, 1976). However while signalling theory provides an indication of the beneficial impact from retained ownership by founders and early stage corporate insiders (directors) that reduces underpricing this effect may be limited (Bruton et al, 2000). At this stage there are considerable differences in the literature relating to the different types of corporate insider i.e. directors and founders. The literature relating to the former would indicate that as their ownership levels increase there may be a mal-alignment of incentives with increasing ownership leading to increasing levels of control and significantly greater potential for opportunistic behaviour due to higher private benefits of control (Busenitz et al, 2005). Bruton et al (2009) find evidence of a trade off effect between incentive alignment and entrenchment effects associated with higher levels of insider ownership and provided evidence of a nonlinear relationship between insider ownership and underpricing. This curvilinear $U$-shaped curve delineated the tradeoff between increased insider efficiency and levels of asymmetric information arising from moral hazard problems. Consequently I test the following hypothesis: 
H-1.1: There is a curvilinear (U-shaped) relationship between underpricing and retained (post-IPO) ownership by the directors acting in their capacity as corporate insiders. Underpricing first decreases and then increases with an increase in their ownership.

However the evidence from Bruton et al (2009) and Busenitz et al (2005) was from US and UK markets. Evidence to the contrary in emerging markets was found by Bouton et al (2009) who presented empirical evidence for the benefits of high levels of insider block-shareholder ownership in legal regimes characterised by poor protection of property rights and minority investors across a comprehensive sample of global IPOs. Furthermore in the context of the very weak legal environments and low levels of protection of property rights afforded in West African markets the increased ownership of founder-entrepreneurs is likely to cause a reduction in underpricing as at high levels of shareholding founders effectively become insider block-shareholders thereby providing an effective governance counter against the potentially detrimental effects of poor external legal protection. Consequently I test the following hypothesis:

H-1.2: There is a curvilinear (inverted U-shaped) relationship between underpricing and retained (post-IPO) ownership by the founders acting in their capacity as corporate insiders. Underpricing first increases and then decreases with an increase in their ownership.

\subsection{Board governance effects on IPO firm performance}

The mainstream international corporate governance literature views an IPO as being the first major "liquidity event" in the life cycle of fast growing firms when founders and initial investors (corporate insiders) begin the process of realizing the value of their ownership stake in the firm (Brav and Gompers, 2003). However the IPO process introduces a number of potential agency conflicts for the various principal and agent parties involved (Bruton et al, 2009). Adverse selection and moral hazard problems arise from the asymmetric information between new owners (investors) and incumbent managers (agents) as there are incentives for the latter to mislead or even worse expropriate the former (Bruton et al (2009); Boulton et al (2009)). As such the board of directors itself can be viewed as being a tool which can act to better align incentives of various principals and agents and facilitate communication and information disclosure thereby reducing asymmetric information (Jensen and Meckling, 1976). The literature regarding the impact of board size on firm performance is largely derived from Jensen (1993) where smaller boards were argued to be the result of technological and organizational change that facilitates reduction of costs and corporate downsizing. Hermalin and Weisbach (2003) found evidence suggesting that smaller boards are more effective than large boards as agency costs increase owing to a greater number of board members adopting the role of free-riders. Jensen (1993) found further evidence for the lack of cohesiveness in large boards leading to a lack of 
coordination and communication that reduced the effectiveness of the board as a monitoring tool in the reduction of agency costs. As such I conjecture that larger boards to be in larger firms with higher value and incurring higher levels of underpricing and cost of equity. Consequently I test the following hypotheses:

H-2.1: Board size is positively associated with IPO-firm value

H-2.2: Board size is positively associated with IPO-firm underpricing

The literature regarding the impact of the founder-entrepreneur retaining a controlling presence as the firm's CEO on firm performance is largely centred around the fears of outside investors regarding high private benefits of control (Busenitz et al, 2005), a mis-alignment of incentives (Roosenboom and Schramade, 2006), propensity for expropriation and tunnelling, and significantly higher agency costs (Bruton et al, 2009). However given West African listings are made up primarily from either former state owned enterprises or small and medium enterprises, of which many are entrepreneurial with founders, I conjecture that founder retaining CEO role is more likely to be associated with smaller firms of low value while underpricing and cost of equity should be higher. As such I test the following hypotheses:

H-2.3: Founder retains CEO role is negatively associated with IPO-firm value

H-2.4: Founder retains CEO role is positively associated with IPO-firm underpricing

The literature regarding the beneficial impact arising from firms establishing independent board level committees to oversee effective information disclosure, executive remuneration and monitoring is more diffuse in its findings. Daily (1995) and Dalton et al (1998) detail how the majority of corporate decision-making is not undertaken through the committees but rather by the board itself while Shivdasani and Yermack (1999) question the independence of committees from CEO control. However given that the establishment of committees with at least nominal independence is a costly process for firms and is recommended in best practice governance guidelines in OECD and Cadbury Report I conjecture that the signalling of quality role of committee establishment will reduce underpricing and costs of equity while being associated with better capitalized, larger value firms that are able to implement these costly procedures. Consequently I test the following hypotheses:

H-2.5: Establishment of committee(s) is positively associated with IPO-firm value 
H-2.6: Establishment of committee(s) is negatively associated with IPO-firm underpricing

CEO duality with the role of Chairman has been critically appraised in the literature with a considerable consensus citing that role duality serious impedes the independent monitoring capacity of boards (Fama (1980); Fama and Jensen (1983)). Consequently I conjecture that role duality is more likely in smaller lower value firms and will be more likely associated with higher levels of underpricing and cost of equity. Consequently I test the following hypotheses:

H-2.7: Separation of CEO-Chairman roles is negatively associated with IPO-firm value

H-2.8: Separation of CEO-Chairman roles is positively associated with IPO-firm underpricing

OLS regressions were used to test these hypotheses using unbalanced panels. This takes the form:

$$
\begin{aligned}
& \text { Performance }_{i}=\text { Cons } \tan t+\beta_{\text {Governance } \text { Governance }+\beta_{\text {Legal }} \text { Legal Controls }_{i}} \\
& +\beta_{\text {Firm }} \text { Firm Controls }_{i}+\varepsilon_{i}
\end{aligned}
$$

where performance is dependent variable relating to firm value and underpricing (both 2 weeks and 180 days) respectively as defined in sections 3.1 to 3.2. Committee, CEO equals Chairman and Founder equals $\mathrm{CEO}$ are dichotomous pulse dummy variables taking value 1 if condition is satisfied and 0 otherwise. Board size is the total number of both executive and non-executive directors and is taken to include those "executive directors" in civil code markets where boards are unitary in structure and supervisory in function.

Legal control variables are introduced as a dichotomous pulse dummy variables, taking value 1 if the market adheres to civil code law and 0 otherwise, where a comprehensive list of civil and common law countries is provided in La Porta et al (2008). Log contract enforcement is the natural logarithm of the number of days taken in judicial process for contract resolution which is detailed in World Bank (2005).

Where governance represents each of the parameters indicated in the hypotheses and Firm and IPO controls are introduced from the literature. Firm-level controls used in each case include firm size, the natural logarithm of tangible assets as expressed in US\$ (Filatotchev and Bishop (2002); Filatotchev et al (2005)). Equally given debt may have a governance role limiting the level of managerial discretion and mitigating potential agency conflicts (Bruton et al, 2009). As such I control for possible effects of debt on IPO valuations in using the total debt-to-total asset ratio. Given the inclusion of a very wide variety of firms undergoing IPOs ranging from the privatizations of very large former state owned enterprises to smaller high growth technology companies with considerable 
variation in revenues this is controlled for by the natural logarithm of US\$ converted revenues in IPO year.

\subsection{Determinants of firms establishing committees and initiating separation of CEO-Chairman role}

I study the determinants of firms initiating the corporate governance mechanisms of splitting the CEO and Chairman roles and establishing committees.

The extent literature regarding the splitting of the CEO and Chairman roles infers that this is less likely in smaller firms which are themselves more likely to have founders retaining control as CEO themselves. It is also more likely in larger firms with larger boards and greater level of board independence. As such I test the following hypotheses:

H-3.1: Splitting of the CEO-Chairman role is more likely to be negatively associated with the founder retaining control in role of CEO.

H-3.2: Splitting of the CEO-Chairman role is more likely to be positively associated with larger boards.

H-3.3: Splitting of the CEO-Chairman role is more likely to be positively associated with higher degree of board independence.

The literature regarding the establishment of committees would infer that these are more likely to be established in larger firms with larger boards which by virtue of size are less likely to have founders retaining controlling position as CEO. However the relationship of committee establishment and levels of board independence is much less clear given the inconclusive literature in this area.

H-3.4: The establishment of committees is more likely to be negatively associated with the founder retaining control in role of CEO.

H-3.5: Splitting of the CEO-Chairman role is more likely to be positively associated with larger boards.

H-3.6: Splitting of the CEO-Chairman role is more likely to be negatively associated with higher degree of board independence. 
These hypotheses are tested using logistic (Logit) regressions with dichotomous dependent variable taking the value of 1 for those firms that have either established committees or in a second model have split the roles of CEO and Chairman and 0 otherwise. The Logit regression is of the form:

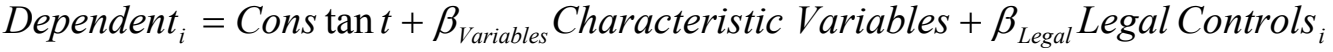

$$
\begin{aligned}
& +\beta_{\text {Firm Controls }} \text { Firm Controls }+\varepsilon_{i}
\end{aligned}
$$

While Founder equals CEO and Board size have been defined in previous section board independence is introduced and measures the proportion of non-executive to executive directors. Together these three variables form the characteristic variables in model. Firm controls are defined in previous sections.

\subsection{Determinants and effects of CEO and Director-shareholder retained ownership}

The role of CEO and director's retained ownership post-IPO are argued to have a major beneficial impact on firm governance especially in countries with weaker levels of investor protection such as those adhering to civil code law as opposed to common law (Boulton et al, 2009). This is especially true in terms of signalling quality given both types of shareholder forfeit opportunities to diversify portfolios in order to maintain costly ownership in their own firm thereby signalling quality to potential outside investors. As a consequence of the differences in legal regime and inferred protection of property rights there are likely to be significant differences in ownership between civil and common law regimes (La Porta et al, 2008).

As such increased CEO shareholding will be more likely to be associated with governance enhancing measure of committee establishment and a split in the roles of CEO and Chairman while being negatively associated with board size. However it is also highly likely associated with founder retaining role of CEO as in line with Boulton et al (2009) the founder is also likely to be the dominant corporate insider block-shareholder in SME firms. As such I test the following hypotheses:

H-4.1: CEO retained ownership is negatively associated with CEO equals Chairman

H-4.2: CEO retained ownership is positively associated with establishment of committee(s)

H-4.3: CEO retained ownership is positively associated with Founder equals CEO

H-4.4: CEO retained ownership is negatively associated with board size 
Director-level shareholding is more diffuse in nature and less focussed on the motivations of a single individual. However this will be more likely to be negatively associated with duality in the CEOChairman role while being positively associated with the establishment of committees. The relationship with the founder retaining CEO role is less clear although this is likely to be a positive association given the founder is likely to fill director posts with family members and exert pervasive dominance over board affairs and hence concentrated insider ownership. Director retained shareholding is also likely to be positively associated with board size given the strength of incentives for insider corporate block-shareholder ownership (Boulton et al, 2009). As such I test the following hypotheses:

H-4.5: Director retained ownership is negatively associated with CEO equals Chairman

H-4.6: Director retained ownership is positively associated with establishment of committee(s)

H-4.7: Director retained ownership is positively associated with Founder equals CEO

H-4.8: Director retained ownership is positively associated with board size

OLS regressions were used to test these hypotheses using unbalanced panels. This takes the form:

$$
\begin{aligned}
& \text { Ownership }_{i}=\text { Cons } \tan t+\beta_{\text {Variables }} \text { Variables }+\beta_{\text {Firm Controls }} \text { Firm Controls } \\
& +\beta_{I P O} \text { IPOControls }_{i}+\varepsilon_{i}
\end{aligned}
$$

where Ownership is percentage retained ownership by CEO in first model and directors in second model post-IPO. Characteristic, Firm and Legal control variables are defined in sections 3.1 to 3.3.

However a higher level of ownership by insiders, and in particular directors, is likely to be reflected in levels of underpricing. The literature is divided over this issue with Boulton et al (2009) citing considerable evidence for the beneficial monitoring role of corporate insider block-shareholders in poorly protected and enforced legal regimes while Jensen and Meckling (1976) and Fama (1980) cite that enhanced ownership and control by directors is potentially detrimental to firm value and increases moral hazard and asymmetric information. Consequently I conjecture that higher levels of director level ownership have a positive impact on underpricing. As such I test the following hypothesis:

H-4.9: Retained director ownership is positively associated with underpricing in IPO firms 
The testing of these hypotheses is complicated given the presence of endogeneity issues and the potential for reverse causation between levels of block-shareholder ownership and underpricing and vice-versa. However while this is of particular concern in developed markets that commonly adhere to common law the less developed nature of civil code markets and in particular those of the West African nations infers that market-determined outcomes of levels of ownership are less likely (Filatotchev et al (2005); Kaserer and Moldenhauer (2008)). As such the degree of reverse causation and feedback between variables is somewhat mitigated.

Given the considerable consternation regarding these endogeneity issues the employment of two stage least squares (2SLS) techniques using instruments variables is preferable to the standard OLS methods. Two-stage least squares (2SLS) is a special case of instrumental variables regression. This employs two distinct stages with the first stage finding the portions of the endogenous and exogenous variables that can be attributed to the instruments. This stage involves estimating an OLS regression of each variable in the model on the set of instruments. The second stage is a regression of the original equation, with all of the variables replaced by the fitted values from the first-stage regressions. The coefficients of this regression are the 2SLS estimates. Firm and Legal control variables are as defined in previous sections. Additional Instrument variables used are both dichotomous with Underwriter is foreign and Founder on board taking value 1 if condition is satisfied and 0 otherwise. These instruments are justified on justified on basis of low correlations with all other variables

\section{EMPIRICAL RESULTS}

\subsection{Descriptive statistics}

The evidence from Table 2 reveals considerable differences between civil and common law markets across West Africa. Mean levels of underpricing and absolute numbers of IPOs are three times greater in common law markets than in their civil law counterparts. However the greatest differential is in the amounts raised between the two types of markets. Mean IPO gross placement proceeds in common law markets of Ghana and Nigeria are over ten times that of the mean amount raised in the civil law markets of BRVM, Cameroon and Cape Verde Islands. These findings alone lend substantial support for the evidence in La Porta et al (2008) regarding considerable differences between the two legal regimes where firms in civil code law markets are more likely to raise capital from internal sources or relationship-based banking systems while firms in common law countries are more market-orientated owing to improved investor protection.

Tables 2 and 3 
The evidence from Table 3 reveals both low levels of correlation across variables within the sample and a general lack of statistical significance of the correlations that do exist. This would infer that multicollinearity is not a significant concern for this sample in the ensuing regression models.

\subsection{IPO Firm underpricing}

The evidence from Figure 1 reveals that there is a curvilinear (U-shaped) relationship between director ownership and underpricing in line with expectations from hypothesis 1.1. Underpricing first decreases to a minimum owing to incentive alignment issues before increasing owing to increasing concerns over conflicts of interest and high private benefits of control. Equally consistent with hypothesis 1.2 the evidence from Figure 2 reveals that the relationship between founder retained ownership post-IPO and underpricing is inverted curvilinear (inverted U-shape). The relationship is initially dominated by concerns over entrenchment, expropriation and high private benefits of control before these subside when ownership reaches approximately $60 \%$ where underpricing peaks and then decreases as the benefits from the presence of large corporate insider block-shareholder becomes apparent (Boulton et al, 2009) in terms of an enforcement mechanism for the protection of property rights where investors have little recourse in the external legal system.

\section{Figures 1 and 2}

The evidence from Tables 4 and 5 relate to underpricing which is reported in the first table at 2 weeks post-IPO and then at 180 days post-IPO in the second. However caution must be exercised as due to missing variables the sample size has decreased to 27 IPO firms which has led to the minimising of the number of independent variables included in line with Good and Hardin (2009). The evidence from models 1 to 4 in Table 1 and models 5 to 8 in Table 2 is broadly consistent with large, positive and generally statistically significant relationships between the establishment of board level committees (such as audit, remuneration and accounting) and board size with underpricing. This is largely consistent with hypotheses 2.2 and 2.6. This evidence would indicate that larger boards act to reduce coordinative efficiency and communication between directors and hence increase the likelihood of asymmetric information and agency cost reflected in underpricing. However it also indicates serious shortcomings in the application of standard models of corporate governance in the West African region with the establishment of board level committees at best being deemed superfluous and lacking in genuine independence as an effective director level monitoring device. This is a particularly serious issue in world regions that are dominated by very strong and pervasive informal institutions and weak levels of legal enforcement and property rights protection.

However there is less discernable relationship between underpricing and the governance variables representing the separation of roles of CEO and Chairman and the retention of the founder 
as board CEO. While these coefficients are large and positive in models 1 and 3 in Table 4 and in model 5 in Table 5 the negative sign in model 7 as well as lack of statistical significance across any of the models infers a lack of consistency with hypotheses 2.4 and 2.8. Generally across all underpricing models the explanatory power is considerably increased through the inclusion of committee and board size variables indicating the relative strength of these two governance parameters in explaining underpricing.

In terms of the legal and firm levels control variables and there is a consistently negative and statistically significant relationship between legal origin and underpricing indicating that this is more prevalent in common law countries. Equally there is a large positive and generally statistically significant relationship between underpricing and natural logarithm of contract enforcement time (in days) revealing underpricing is more prevalent in legal systems characterised by inefficiencies and high levels of structural rigidity and bureaucracy. Generally there is a large negative and significant relationship with log tangible assets, which is a proxy for firm size, and a large positive relationship with log revenues indicating underpricing is more prevalent for larger firms with higher revenues. There is little statistical significance in relationship with total debt to total assets ratio although this is generally large and positive.

\section{Tables 4 and 5}

\subsection{IPO Firm value}

The evidence from Table 6 from the regressions of individual governance variables on firm value, in models 9 to 12 is largely consistent with hypotheses predictions in 2.1,2.3, 2.5 and 2.7. It must be noted that in line with the earlier underpricing models the choice of the number of independent variables was made following Good and Hardin (2009) owing to a sample size of 27 caused from missing variables amongst the IPO firms. However negative relationships are found between every governance variable and firm value except for board size, although only the coefficients associated with the separation of CEO and Chairman and the establishment of board level committees are statistically significant at the $90 \%$ confidence level. These would infer that higher value firms are less likely to have CEO as Chairman, less likely to establish expensive committees as a best practice governance measure and less likely to have founder retaining role of CEO while more likely to have larger boards although the latter two relationships lack statistical significance at a high level of confidence. The explanatory power of all models is high being over $45 \%$ indicating these governance parameters explain much of the variance in firm value across the sample.

There are some notable relationships between firm and legal control variables and firm value. The negative and largely statistically significant legal origin coefficient indicates that firms of higher value are more likely to be in common law markets while the positive and only marginally significant relationship with $\log$ contract enforcement indicates that firms of higher value are more likely to be 
located in weaker legal regimes. While this may seem at first glance counter-intuitive to the results of Levine (2005) and La Porta et al (2008) there are considerable structural inefficiencies in the legal enforcement and protection of property rights in Ghana and Nigeria where conclusion of contracts takes 200 and 730 days respectively in contrast to substantially shorter times in the civil code markets of Cape Verde, Cote d'Ivoire and Cameroon (World Bank, 2005). Finally a negative and strongly significant relationship with $\log$ revenues indicates that firms with higher market values have consistently lower revenues.

\section{Table 6}

\subsection{Determinants of firms establishment of committees and separating role of CEO-Chairman}

The evidence from logistic regression regarding the determinants behind firms separating the roles of CEO and Chairman and establishing committees is provided in Table7. Model 13 reveals that duality of the CEO and Chairman is negatively associated with founder retaining CEO position. While this is consistent with hypothesis 3.1 it infers that founder-entrepreneurial firms are more likely to instigate corporate governance best practice. The positive relationships between CEO-Chairman duality lack statistical significance at any discernable confidence level but the positive coefficients offers weak support for refuting hypotheses 3.2 and 3.3. The explanatory power of this model is reasonable at $34.66 \%$ although this is significantly lower than in model 14 which assess the determinants for firms to establish independent committees. The evidence in model 14 reveals stronger and overall more statistically significant relationships with the establishment of a committee being negatively and statistically significant to the founder retaining role of CEO which is consistent with hypothesis 3.4. Equally the establishment of a committee is negatively and statistically significantly related to board independence, consistent to hypothesis 3.6, which provides more evidence alluding to the lack of genuine independence of committees and their inability to provide effective monitoring. Lastly there is a weak positive relationship with board size which lacks significance at any discernable confidence level providing inconclusive evidence relating to hypothesis 3.5. The negative and statistically significant relationship between committee establishment and the control variable total debt to total assets indicates committees are more likely established in firms with higher levels of debt. Debt is a more common form of relationship-based finance across West Africa and consequently the establishment of committees may be perceived as being an attempt by firms that finance their operations primarily by debt and have been motivated to list due to political pressure in adopting governance best practice at least nominally.

\section{Table 7}

\subsection{Determinants and effects of director-shareholder ownership}


The evidence relating to the determinants of CEO and director ownership is provided in models 15 and 16 in panel 1 of Table 8. The relationships in model 15 relating to retained CEO ownership are largely consistent to the hypotheses 4.1 to 4.4. Increased CEO ownership is negatively and significantly related to CEO equals Chairman, positively but not significantly related to establishment of committees while being positively and significantly related to CEO equals founder. Lastly retained CEO ownership is negatively and significantly related to board size. None of the legal or firm controls are statistically significant. This would infer that CEO ownership is strongly related to the separation of the roles of CEO and Chairman, which is a key governance indicator of quality. However it is also related to smaller boards and with the founder retaining CEO role which infers that CEO ownership is concerned with enhanced control of the CEO over corporate affairs and a general lack of independence. This is particularly relevant in explaining the early stages of the relation between director ownership and underpricing in the earlier Figure 1. The explanatory power of this model is high at over $78 \%$. The evidence from model 16 regarding the more general retained ownership by directors, which includes that of the CEO, exhibits relationships that are very similar to those of the earlier CEO ownership and consistent with hypotheses 4.5 to 4.8 . However the relationship with board size is now positive and lacking statistical significance. As such the determinants of increased director level retained ownership is negatively related to role duality between CEO and Chairman, positively related with founder retaining CEO role and interestingly positively and highly significantly related to the establishment of committees. This would infer that while corporate insider entrenchment is a concern for increased director ownership the establishment of committees may be perceived by West African investors as actually being more closely associated with the dominance of insiders rather than as an effective monitoring mechanism. Lastly the negative and significant legal origin coefficient indicates that retained director ownership is more likely in common law markets which is in line with the findings of Boulton et al (2009) while it is associated with lower levels of debt in relation to total firm assets.

\section{Table 8}

The evidence from panel 2, Table 8 regarding the results from the 2 stage least squares (2SLS) regression reveals that retained director ownership has a small positive but highly significant impact on underpricing. Mindful of the inference issues associated with very small samples and in particular a lack of degrees of freedom a lower number of variables were included in model in line with recommendations in Good and Hardin (2009). Directors retention of ownership can be viewed both as a costly signal of quality owing to their sacrificing opportunities to diversify risk as opposed to retaining investment in the high quality venture while also being a concern to outside investors owing to their entrenchment and potential high private benefits of control. Interestingly the effect of increased retention of director shareholding leading to higher underpricing is more prevalent in civil 
code markets and those markets with weaker legal regimes, as shown by the positive coefficients on both the legal origin and log contract enforcement control variables. All firm controls lack statistical significance at any discernable confidence level. The explanatory power of this model is over $20 \%$ inferring some strength in the explanation of variation underpricing across the sample.

Overall these results would question the wholesale adoption of best practice corporate governance legislation by authorities in regions where domestic informal institutions, engendered in language and traditional values, are often at odds with the formal institutions inherited from former colonial metropoles. These findings are especially pertinent to smaller developing markets where competition for foreign portfolio and direct investment is more competitive in the current economic climate following the recent financial crisis of 2008/2009.

\section{CONCLUSIONS}

This study investigates the impact of common best practice governance measures on the performance comprehensive sample of IPO firms across the West African region for the period 2000 to 2009. While the region is characterised by low levels of property rights protection, ineffective legal enforcement and structural rigidity in legal systems which lead to potentially high private benefits of control for corporate insiders the evidence suggests that only some of the globally standard best practice governance mechanisms are beneficial. These findings are especially pertinent given that many less developed emerging markets are characterised by both the dominance of social elites in political economy and informal institutions that engender different economic and social outcomes from those envisaged in those inherited from former colonial metropoles. This is of particular importance given the enhanced emphasis on the role of corporate governance legislation and the dominance of the Anglo-American shareholder value and European stakeholder models in development policy.

The findings suggest that the establishment of independent audit and remuneration committees to monitor directors and insiders is at best superfluous with their presence actually increasing levels of asymmetric information and underpricing. This would indicate that outside investors actually view committees as being formally under the control of directors and insiders which would intuitively be expected in highly relationship-based network political economies which place considerable emphasis on adherence to traditional values and identity. However the separation of the roles of CEO and Chairman and the founder-entrepreneur ceding control of CEO role are beneficial mechanisms in signalling quality to potential outside investors. However while these governance mechanisms imply benefits from a reduction in asymmetric information and underpricing in line with research in UK and US larger boards have greater coordination and communication problems and their presence is reflected in higher levels of underpricing. 
A major concern across West African IPO firms is the impact from high private benefits of control arising from too much control and ownership being vested in too few individuals. Both CEO and director ownership is determined largely by whether the founder retains the position of CEO as well as board size inferring concerns over moral hazard arising from CEO control and domination of the board. This is especially evident with a very large relationship between underpricing and the presence of committees indicating that investors perceive these in a very different way from their Western counterparts in lacking genuine independence and ability to effectively monitor. In conclusion while West African firms have adopted corporate governance mechanisms from international best practice guidelines only some of these recommendations are likely to be effective in the distinctive relationship-focussed business environment with narrow political economies characterised by social allegiances to traditional values. 


\section{Acknowledgements}

I am grateful for the useful comments and advice from Jenifer Piesse and Ron Smith in completing this work. I am also grateful to Nadia Oumalik and Olive Kone for assistance in the translation of BRVM (Cote d'Ivoire) and Cameroonian prospectuses and Lilian de Menezes for Portuguese to English translation of Cape Verde Islands prospectuses. I am very grateful for useful comments from the participants of the Academy of International Business annual conference, Rio de Janeiro, Brazil June 2010 and the Asian Financial Association Conference, Hong Kong July 2010. 


\section{REFERENCES}

Akotey, A. J. (2007) Interview with Armah Akotey, Vice President of Investments, Databank Brokerage Ltd, Accra, Ghana. 23 December 2008.

Anderson, R., Mansi, S. \& Reeb, D. (2003). Founding family ownership and the agency costs of debt. Journal of Financial Economics, 68, 263-285

Boulton, T. J., Smart, S. B., \& Zutter, C. J. (2009). IPO underpricing and international corporate governance. Journal of International Business Studies, 1-17

Brav, A., \& Gompers, P. (2003). The role of lock-ups in initial public offerings. The Review of Financial Studies, 16, 1-29

Brennan, M. J. \& Franks, J. (1997). Underpricing, ownership and control in initial public offerings of equity securities in the UK. Journal of Financial Economics, 45, 391-413

Bruton, G. D., Filatotchev, I., Chahine, S., \& Wright, M. (2009). Governance, Ownership Structure, and Performance of IPO Firms: The Impact of Different Types of Private Equity Investors and Institutional Environments. Strategic Management Journal, forthcoming

Busenitz, L. W., Fiet, J. O. \& Moesel, D. D. (2005). Signaling in venture capital - New venture team funding: Does it indicate long-term venture outcomes? Entrepreneurship, Theory \& Practice, $29,1-12$

BVC website (2010). Bolsa de Valores de Cabo Verde. http://www.bvc.cv/ Accessed 20 May 2010

Chang, S. (2003). Ownership structure, expropriation, and performance of group-affiliated companies in Korea. Academy of Management Journal, 46, 238-254

Claessens, S. (2003). Corporate governance and development. In: Sir Adrian Cadbury, (Ed), Global corporate governance forum. International Bank for Reconstruction and Development/ The World Bank: Washington DC

Daily, C. M. (1995). The relationship between board composition and leadership structure and bankruptcy reorganization outcomes. Journal of Management, 21, 1041-1056

Daily, C. M., Dalton, D. R. \& Canella, A. A. (2003). Corporate Governance: Decades of Dialog and data. Academy of Management Review, 28(3), 371-398

Dalton, D. R., Daily, C. M., Ellstrand, A. E. \& Johnson, J. L. (1998). Meta-analytic review of board composition, leadership structure, and financial performance. Strategic Management Journal, $19,269-290$

Downes, D. H. \& Heinkel, R. (1982). Signalling and valuation of unseasoned new issues. Journal of Finance, 37(1), 1-10

DSX website (2010). Bourse de Doula. http://www.douala-stock-exchange.com/index_us.php Accessed 20 May 2010

Fama, E. F. (1980). Agency problems and the theory of the firm. Journal of Political Economy, 88(8), 288-307 
Fama, E. F. \& Jensen, M. C. (1983). Separation of ownership and control. Journal of Law and Economics, 26, 301-325

Filatotchev, I, \& Bishop, K. (2002). Board Composition, Share Ownership, and "Underpricing” of UK IPO Firms. Strategic Management Journal, 23, 941-955

Filatotchev, I., Lien, Y-C., \& Piesse, J. (2005). Corporate governance and performance in publically listed, family-controlled firms: Evidence from Taiwan. Asia-Pacific Journal of Management, $22,257-283$

Filatotchev, I., \& Wright, M. (2005). The life cycle of corporate governance. Edward Elgar: Chltenham, UK.

Fosu, A., Bates, R., \& Hoeffler, A. (2010). Institutions, governance and economic development in Africa: An overview. Journal of African Economies, 15(1), 1-9

Golden, B. R. \& Zajac, E. J. (2001). When will boards influence strategy? Inclination x Power = Strategic Change. Strategic Management Journal, 22, 1087-1111

Gompers, P. A. (1996). Grandstanding in the venture capital industry. Journal of Financial Economics, 42, 133-156

Gompers, P., Kovner, A., Lerner, J., \& Scharfstein, D. (2008). Venture capital investment cycles: The impact of public markets. Journal of Financial Economics, 87, 1-23

Good, P. I. and Hardin, J. W. (2009). Common Errors in Statistics (And How to Avoid Them), 3rd ed., Hoboken, New Jersey: Wiley

Hayek, F. A. (1960). The Constitution of Liberty. Chicago: University of Chicago Press

Hearn, B., \& Piesse, J. (2009). Barriers to the development of small stock markets: A case study of Swaziland and Mozambique. Journal of International Development, forthcoming

Hearn, B., \& Piesse, J. (2010). Modelling size and illiquidity in West African equity markets. Applied Financial Economics, Forthcoming, 1-20

Hermalin, B. \& Weisbach, M. (2003). Boards of directors as an Endogenously determined institution: a survey of the economics literature. Economic Policy Review, 9, 7-26

Hoskisson, R. E., Cannella, A. A., Tihanyi, L., \& Faraci, R. (2004). Asset restructuring and business group affiliation in French civil law countries. Strategic Management Journal, 25(6), 525539

Jensen, M. C., \& Meckling, W. (1976). Theory of the firm: managerial behavior, agency costs, and ownership structure. Journal of Financial Economics, 3, 305-360

Jensen, M. (1993). The modern industrial revolution, exit, and the failure of internal control systems. Journal of Finance, 48, 831-880

Joireman, S. F. (2001). Inherited legal systems and effective rule of law: Africa and the colonial legacy. Journal of Modern African Studies, 39(4), 571-596

Joireman, S. F. (2005). The Evolution of the Common Law: Legal Development in Kenya and India. 
Commonwealth and Comparative Politics, 21, 190-210

Kalbers, L. P. \& Fogarty, T. J. (1998). Organizational and Economic Explanations of Audit Committee Oversight. Journal of Managerial Issues, 10(2), 129-151

Kaserer, C., \& Moldernhauer, B. (2008). Insider ownership and corporate performance; evidence from Germany. Review of Management Studies, 2, 1-35

Kirkpatrick, G. (2009). The corporate governance lessons from the Financial Crisis. Financial Markets Trends working paper series, OECD. ISSN 1995-2864

La Porta, R., Lopez-de-Silanes, F., Schliefer, A., \&Vishny, R. (1997). Legal Determinants of External Finance. Journal of Finance, 52, 1131-1150

La Porta, R., Lopez-de-Silanes, F., Schliefer, A., \&Vishny, R. (1998). Law and Finance. Journal of Political Economy, 106(6), 1113-1155

La Porta, R., Lopez-de-Silanes, F., \& Schliefer, A. (1999). Corporate Ownership Around the World, Journal of Finance, 24(2), 471-517

La Porta, R., Lopez-de-Silanes, F., Schliefer, A., \&Vishny, R. (2000). Investor protection and corporate governance. Journal of Financial Economics, 58, 3-27

La Porta, R., Lopez-de-Silanes, F. \& Shleifer, A. (2008). The Economic Consequences of Legal Origins, Journal of Economic Literature, 46, 285-332

Lavelle KC. 2001. Architecture of Equity Markets: The Abidjan Regional Bourse. International Organisation, 55:3, 717-42

Leland, H. E. \& Pyle, D. H. (1977). Informational asymmetries, financial structure, and financial intermediation. Journal of Finance, 32, 371-387

Levine, R. (2005). Law, Endowments and Property Rights. Journal of Economic Perspectives, 19(3), $61-88$

O’Hara, M. (2003) Presidential address: liquidity and price discovery. Journal of Finance, 58, 13351354

Puranandam, A. K., \& Swaminathan, B. (2004). Are IPOs really underpriced? Review of Financial Studies, $17,811-848$

Roosenboom, P. \& Schramade, W. (2006). The price of power: Valuing the controlling position of owner-managers in French IPO firms. Journal of Corporate Finance, 12, 270-295

Schleifer, A. \& Vishny, R. W. (1997). A Survey of Corporate Governance. Journal of Finance, 52 (2), $737-783$

Shane, S. \& Cable, D. (2002). Network ties, reputation, and the financing of new ventures. Management Science, 48(3), 364-381

Shenone, C. (2004). The effect of banking relationships on the firm's IPO underpricing. Journal of Finance, LIX(6), 2903-2958 
Shivdasani, A. \& Yermack, D. (1999). CEO involvement in the selection of New Board members: An empirical analysis. Journal of Finance, 54, 1829-1853

Smith, G., \& Jefferis, K. (2005) The Changing Efficiency of African Stock Markets, South African Journal of Economics, 73(1), 54-67

Turley, S. \& Zaman, M. (2004). The corporate governance effects of audit committees. Journal of Management and Governance, 8(3), 305-332

World Bank (2005). Doing business in Africa report. http://www.doingbusiness.org/ Accessed 21 January 2010 
Table 1. IPO sample characteristics by country

\begin{tabular}{|c|c|c|c|c|c|c|}
\hline Country & $\mathbf{N}_{\text {Total }}$ & $\overline{\mathbf{N}_{\text {Sample }}}$ & Sector & Head Office Location & Primary Listing Market & Purpose of listing \\
\hline \multirow[t]{4}{*}{ BRVM } & \multirow[t]{4}{*}{8} & 1 & Telecommunications & Burkina Faso & BRVM-Cote d'Ivoire & Local fund raising \\
\hline & & 1 & Finance & Niger & BRVM-Cote d'Ivoire & UMEAO financial integration \\
\hline & & 1 & Finance & Benin & BRVM-Cote d'Ivoire & UMEAO financial integration \\
\hline & & 1 & Distribution & Cote d'Ivoire & BRVM-Cote d'Ivoire & Local fund raising \\
\hline Cameroon & 3 & 1 & Agro-commodities & $\begin{array}{l}\text { French multinational } \\
\text { (Other locations include } \\
\text { Cambodia and France) }\end{array}$ & Bourse de Douala & $\begin{array}{l}\text { Indigenisation/ Sale of Cameroonian } \\
\text { privatization agency (La Societe Nationale } \\
\text { d'investissement du Cameroun) }\end{array}$ \\
\hline \multirow{2}{*}{$\begin{array}{l}\text { Cape Verde } \\
\text { Islands }\end{array}$} & \multirow[t]{2}{*}{4} & 2 & Finance & Cidade da Praia & Bolsa de Valores de Cabo Verde & Local fund raising \\
\hline & & 1 & Oil Refinery & Mindelo, São Vicente & Bolsa de Valores de Cabo Verde & Privatization \\
\hline \multirow[t]{9}{*}{ Ghana } & \multirow[t]{9}{*}{15} & 2 & Finance & Accra & Accra-Ghana Stock Exchange & Privatization \\
\hline & & 1 & Finance & Accra & Accra-Ghana Stock Exchange & Local fund raising \\
\hline & & 1 & Finance & Banjul, The Gambia & Accra-Ghana Stock Exchange & $\begin{array}{l}\text { Political: Anglophone West African financial } \\
\text { integration* }\end{array}$ \\
\hline & & 1 & Consumer Staples & Accra & Accra-Ghana Stock Exchange & Local fund raising \\
\hline & & 1 & Consumer Staples & Accra & Accra-Ghana Stock Exchange & Privatization \\
\hline & & 1 & Consumer Products and Services & Accra & Accra-Ghana Stock Exchange & Local fund raising \\
\hline & & 2 & High Technology & Accra & Accra-Ghana Stock Exchange & Local fund raising \\
\hline & & 1 & Industrials & Accra & Accra-Ghana Stock Exchange & Privatization \\
\hline & & 1 & Industrials & Accra & Accra-Ghana Stock Exchange & Privatization and Merger \\
\hline \multirow[t]{7}{*}{ Nigeria } & \multirow[t]{7}{*}{$27 * *$} & 4 & Finance & Lagos & Lagos-Nigeria Stock Exchange & Local fund raising \\
\hline & & 3 & Finance & Lagos & Lagos-Nigeria Stock Exchange & Indigenisation/ Spin-off \\
\hline & & 2 & Finance & Lagos & Lagos-Nigeria Stock Exchange & Local fund raising \\
\hline & & 4 & Consumer Staples & Lagos & Lagos-Nigeria Stock Exchange & Spin-Off from conglomerate \\
\hline & & 1 & Hotels and Accommodation & Lagos & Lagos-Nigeria Stock Exchange & Privatization \\
\hline & & 1 & Industrials & Lagos & Lagos-Nigeria Stock Exchange & Spin-Off from conglomerate \\
\hline & & 1 & Media and Entertainment & Abuja & Lagos-Nigeria Stock Exchange & Local fund raising \\
\hline
\end{tabular}

Source: Compiled by author from prospectuses obtained direct from national stock exchanges and Thomson Perfect Information

Notes: (1) $\mathbf{N}_{\text {Sample }}$ indicates sample IPO firms

(2) $\mathbf{N}_{\text {Total }}$ indicates total number of IPOs undertaken in market (obtained from official national stock exchange lists)

(3) ** indicates estimated number of IPOs owing to uncertainty stemming from local definition of IPO being merged with that of private placement and other listings

(4) *indicates that the listing of Gambia's Trust Bank was facilitated by Ghana's Databank securities firm. This has involved the establishment of a small office in

Banjul, Gambia through which order flow from the Gambia is precipitated. The listing was motivated politically as part of Anglophone English common law West

Africa and through Trust Bank's expansion into other Anglophone regional markets. 
Table 2. IPO descriptive statistics by country

This table presents the distribution of IPOs and initial returns statistics by listing country. Initial return is the secondary market closing price at end of second week of listing divided by the final offer price, minus 1 .

\begin{tabular}{|c|c|c|c|c|c|c|c|c|}
\hline \multirow[t]{2}{*}{ Legal Origin } & \multirow[t]{2}{*}{ Country } & \multicolumn{3}{|c|}{ Initial Returns } & \multicolumn{4}{|c|}{ IPO Gross Placement Proceeds US\$m } \\
\hline & & $\mathbf{N}$ & Mean & Median & Std. dev. & Mean & Median & Std. dev. \\
\hline \multirow[t]{2}{*}{ French civil code } & BRVM/ Cote d'Ivoire & 4 & 0.141 & 0.106 & 0.098 & 16.340 & 1.789 & 29.864 \\
\hline & Cameroon & 1 & 0.000 & 0.000 & 0.000 & 6.144 & 6.144 & 0.000 \\
\hline Portuguese civil code & Cape Verde Islands & 4 & 0.011 & 0.008 & 0.013 & 9.094 & 8.435 & 6.403 \\
\hline Civil Code Law & & 9 & 0.113 & 0.072 & 0.105 & 11.987 & 4.042 & 19.176 \\
\hline English common law & Ghana & 13 & 0.079 & 0.000 & 0.234 & 11.797 & 2.970 & 18.287 \\
\hline Common law & & 28 & 0.302 & 0.109 & 0.671 & 113.465 & 53.285 & 177.505 \\
\hline
\end{tabular}

Table 3. Pearson correlation statistics for Firm characteristics at the time of IPO

\begin{tabular}{|c|c|c|c|c|c|c|c|c|c|c|c|c|c|c|c|c|}
\hline & & 1 & 2 & 3 & 4 & $\overline{5}$ & $\overline{6}$ & 7 & 8 & 9 & 10 & 11 & 12 & 13 & 14 & 15 \\
\hline 1 & Underpricing ( 2 weeks) & 1.00 & & & & & & & & & & & & & & \\
\hline \multirow[t]{2}{*}{2} & Underpricing (180 & & & & & & & & & & & & & & & \\
\hline & days) & $0.94 \dagger \dagger$ & 1.00 & & & & & & & & & & & & & \\
\hline 3 & Log Firm Value & 0.14 & 0.19 & 1.00 & & & & & & & & & & & & \\
\hline 4 & CEO equals Chairman & 0.26 & 0.13 & $-0.62 * *$ & 1.00 & & & & & & & & & & & \\
\hline 5 & Committee (s) & $0.49 *$ & 0.31 & -0.28 & $0.60 * *$ & 1.00 & & & & & & & & & & \\
\hline 6 & CEO equals Founder & 0.00 & -0.17 & 0.01 & -0.19 & -0.32 & 1.00 & & & & & & & & & \\
\hline 7 & Board Size & 0.37 & 0.21 & 0.29 & $0.48 *$ & 0.41 & 0.06 & 1.00 & & & & & & & & \\
\hline 8 & Board Independence & 0.06 & 0.20 & $0.58 * *$ & -0.34 & -0.32 & -0.24 & 0.03 & 1.00 & & & & & & & \\
\hline 9 & Legal Origin & -- -- & ---- & ---- & -- -- & ---- & -- -- & --- & ---- & ---- & & & & & & \\
\hline \multirow[t]{2}{*}{10} & Log Contract & & & & & & & & & & & & & & & \\
\hline & Enforcement & 0.32 & 0.27 & -0.09 & $0.76 \dagger \dagger$ & 0.32 & -0.25 & $0.67 \dagger$ & 0.30 & ---- & 1.00 & & & & & \\
\hline 11 & Log Tangible Assets & $-0.47^{*}$ & $-0.51 *$ & -0.35 & $0.56^{*}$ & 0.18 & -0.38 & 0.21 & 0.14 & --- & $0.60 * *$ & 1.00 & & & & \\
\hline 12 & Log Revenues & -0.22 & -0.12 & -0.33 & 0.41 & 0.05 & $-0.51 *$ & -0.03 & $0.47 *$ & ---- & $0.60 * *$ & $0.79 \dagger \dagger$ & 1.00 & & & \\
\hline \multirow[t]{2}{*}{13} & Ratio of total debt to & & & & & & & & & & & & & & & \\
\hline & Total Assets & 0.05 & 0.19 & -0.27 & 0.10 & -0.22 & -0.20 & $-0.45^{*}$ & -0.27 & -- -- & -0.08 & -0.15 & -0.09 & 1.00 & & \\
\hline 14 & Director ownership (\%) & -0.01 & -0.01 & 0.25 & -0.32 & $0.45^{*}$ & $-0.44 *$ & -0.07 & 0.10 & --- & -0.36 & -0.08 & -0.04 & $-0.49 *$ & 1.00 & \\
\hline 15 & Founder ownership (\%) & -0.37 & -0.38 & 0.17 & -0.38 & 0.27 & -0.39 & -0.21 & 0.06 & --- & $-0.46^{*}$ & 0.11 & 0.02 & $-0.46^{*}$ & $0.92 \dagger \dagger$ & 1.00 \\
\hline
\end{tabular}

Notes: (1) * Significant at $10 \%$ confidence level; ** Significant at $5 \%$ confidence level; $\uparrow$ Significant at $1 \%$ confidence level;

$\dagger$ Significant at $0.5 \%$ confidence level 
Table 4. OLS regression analysis of corporate governance characteristics, legal and firm controls on IPO Firm underpricing The table presents the OLS estimates of the following regression equation:

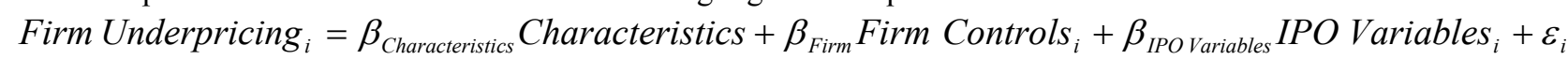

Firm underpricing is estimated at 2 weeks. Characteristic variables, Firm controls are defined in Table 4.

\begin{tabular}{|c|c|c|c|c|}
\hline Independent Variables & Model 1 & Model 2 & Model 3 & Model 4 \\
\hline Intercept & $-152.925(143.40)$ & $-178.791(125.49)^{*}$ & $-157.441(143.28)$ & $-156.378(131.61)$ \\
\hline \multicolumn{5}{|l|}{ Characteristics } \\
\hline CEO equals Chairman & $20.450(43.29)$ & & & \\
\hline Committee (s) & & $67.586(28.38) \dagger$ & & \\
\hline CEO equals Founder & & & $10.160(30.53)^{*}$ & \\
\hline Board Size & & & & $9.089(4.99)^{* *}$ \\
\hline \multicolumn{5}{|l|}{ Legal Controls } \\
\hline Legal Origin & $-39.459(29.33)^{*}$ & $-53.792(26.72)^{* *}$ & $-32.706(33.13)$ & $-28.853(27.59)$ \\
\hline Log Contract Enforcement & $121.770(62.57)^{* *}$ & $126.675(53.07) \dagger$ & $123.502(63.53)^{* *}$ & $94.058(59.15)^{*}$ \\
\hline \multicolumn{5}{|l|}{ Firm Controls } \\
\hline Log Tangible Assets & $-29.367(15.21)^{* *}$ & $-35.693(13.77) \dagger$ & $-28.540(15.38)^{* *}$ & $-38.397(15.04) \dagger$ \\
\hline Log Revenue & $5.943(12.20)$ & $7.476(10.81)$ & $6.524(12.21)$ & $14.751(12.23)$ \\
\hline Total Debt/ Total Assets & $14.583(42.92)$ & $36.306(38.20)$ & $19.788(42.54)$ & $26.338(39.54)$ \\
\hline Fixed Effects & No & No & No & No \\
\hline Observations & 27 & 27 & 27 & 27 \\
\hline F probability & 1.149 & 2.356 & 1.124 & 1.834 \\
\hline F-test all coefficients $=0$ & 0.371 & 0.069 & 0.383 & 0.143 \\
\hline Adjusted R2 & 0.0332 & 0.2384 & 0.0278 & 0.1615 \\
\hline
\end{tabular}

Notes: $\quad(1) * \mathrm{p}<0.10 ; * * \mathrm{p}<0.05 ; \dagger \mathrm{p}<0.01 ; \dagger \uparrow \mathrm{p}<0.005$. Standard errors are in parentheses

(2) White cross-section standard errors \& covariance (d.f. corrected) 
Table 5. OLS regression analysis of corporate governance characteristics, legal and firm controls on IPO Firm underpricing

The table presents the OLS estimates of the following regression equation:

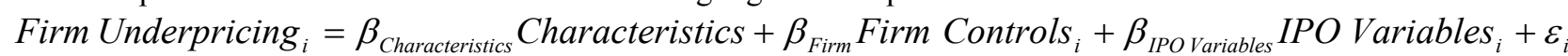

Firm underpricing is estimated at 180 days. Characteristic variables, Firm controls are defined in Table 4.

\begin{tabular}{|c|c|c|c|c|}
\hline Independent Variables & Model 5 & Model 6 & Model 7 & Model 8 \\
\hline Intercept & $-105.694(159.59)$ & $-126.327(152.62)$ & $-126.565(159.20)$ & $-106.562(140.89)$ \\
\hline \multicolumn{5}{|l|}{ Characteristics } \\
\hline CEO equals Chairman & $20.771(48.18)$ & & & \\
\hline Committee (s) & & $41.668(34.51)^{*}$ & & \\
\hline CEO equals Founder & & & $-12.580(33.92)$ & \\
\hline Board Size & & & & $12.125(5.34)^{* *}$ \\
\hline \multicolumn{5}{|l|}{ Legal Controls } \\
\hline Legal Origin & $-16.812(32.64)$ & $-25.026(32.49)$ & $-21.659(36.820)$ & $-3.159(29.54)$ \\
\hline Log Contract Enforcement & $101.820(69.63) * *$ & $108.333(64.54)^{* *}$ & $119.377(70.592)^{* *}$ & $62.068(63.32)$ \\
\hline \multicolumn{5}{|l|}{ Firm Controls } \\
\hline Log Tangible Assets & $-52.797(16.93) \dagger \dagger$ & $-56.627(16.75) \dagger \dagger$ & $-53.430(17.09) \dagger \dagger$ & $-64.898(16.10) \dagger \dagger$ \\
\hline Log Revenue & $25.955(13.58)^{* *}$ & $27.068(13.15)^{* *}$ & $26.184(13.57)^{* *}$ & $37.571(13.09) \dagger \dagger$ \\
\hline Total Debt/ Total Assets & $40.342(47.76)$ & $55.217(46.46)$ & $42.270(47.27)$ & $54.841(42.33)^{*}$ \\
\hline Fixed Effects & No & No & No & No \\
\hline Observations & 27 & 27 & 27 & 27 \\
\hline F probability & 1.806 & 2.129 & 1.793 & 3.070 \\
\hline F-test all coefficients $=0$ & 0.148 & 0.094 & 0.151 & 0.026 \\
\hline Adjusted R2 & 0.1568 & 0.2068 & 0.1548 & 0.3233 \\
\hline
\end{tabular}

Notes: $\quad(1) * \mathrm{p}<0.10 ;{ }^{* *} \mathrm{p}<0.05 ; \dagger \mathrm{p}<0.01 ; \dagger \dagger \mathrm{p}<0.005$. Standard errors are in parentheses

(2) White cross-section standard errors \& covariance (d.f. corrected) 
Table 6. OLS regression analysis of corporate governance characteristics, legal and firm controls on IPO Firm value

The table presents the OLS estimates of the following regression equation:

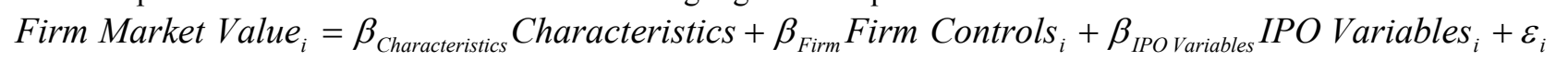

Firm Market value is defined as natural logarithm of ratio of market value of equity on $14^{\text {th }}$ trading day (market price times number of shares outstanding on $14^{\text {th }}$ trading day post-listing) and firm's revenues at the IPO year. Characteristics are defined as dichotomous variables taking value 1 if condition is satisfied and 0 otherwise for private equity presence and lead manager foreign. Lead manager reputation is the cumulative market share of IPO proceeds raised by clients of the lead manager in relation to total IPO proceeds raised on local market while lead manager foreign is dichotomous pulse dummy variable taking value 1 if lead manager is foreign and 0 otherwise. Firm

control variables are natural logarithm of tangible assets (in US\$), natural logarithm of firm age, itself the difference between foundation and listing date, natural logarithm of firm revenues in year preceding listing (in US\$) and ratio of total debt to total assets.

\begin{tabular}{|c|c|c|c|c|}
\hline Independent Variables & Model 9 & Model 10 & Model 11 & Model 12 \\
\hline Intercept & $8.344(3.06) \dagger \dagger$ & $8.991(2.85) \dagger \dagger$ & $8.763(2.91) \dagger \dagger$ & $9.034(3.01) \dagger \dagger$ \\
\hline \multicolumn{5}{|l|}{ Characteristics } \\
\hline CEO equals Chairman & $-0.787(0.91)^{*}$ & & & \\
\hline Committee (s) & & $-0.923(0.63)^{*}$ & & \\
\hline CEO equals Founder & & & $-0.726(0.62)$ & \\
\hline Board Size & & & & $3.013(0.11)$ \\
\hline \multicolumn{5}{|l|}{ Legal Controls } \\
\hline Legal Origin & $-0.724(0.59)$ & $-0.567(0.58)$ & $-1.187(0.66)^{* *}$ & $-0.799(0.61)^{*}$ \\
\hline Log Contract Enforcement & $0.820(1.26)$ & $0.535(1.16)$ & $0.954(1.25)$ & $0.467(1.29)$ \\
\hline \multicolumn{5}{|l|}{ Firm Controls } \\
\hline Log Tangible Assets & $0.279(0.31)$ & $0.361(0.30)$ & $0.190(0.31)$ & $0.255(0.33)$ \\
\hline Log Revenue & $-1.123(0.24) \dagger \dagger$ & $-1.154(0.23) \dagger \dagger$ & $-1.152(0.24) \dagger \dagger$ & $-1.139(0.27) \dagger \dagger$ \\
\hline Total Debt/ Total Assets & $-0.435(0.93)$ & $-0.825(0.87)$ & $-0.854(0.89)$ & $-0.661(0.93)$ \\
\hline Fixed Effects & No & No & No & No \\
\hline Observations & 26 & 26 & 26 & 26 \\
\hline F probability & 4.638 & 5.188 & 4.887 & 4.345 \\
\hline F-test all coefficients $=0$ & 0.004 & 0.002 & 0.003 & 0.006 \\
\hline Adjusted R2 & 0.4661 & 0.5013 & 0.4826 & 0.4453 \\
\hline
\end{tabular}

Notes: $\quad(1) * \mathrm{p}<0.10 ; * * \mathrm{p}<0.05 ; \uparrow \mathrm{p}<0.01 ; \dagger \dagger \mathrm{p}<0.005$. Standard errors are in parentheses

(2) White cross-section standard errors \& covariance (d.f. corrected) 
Table 7. Determinants of corporate governance Logistic regressions

The table presents the Logit estimates of the following regression equation:

Dependent $_{i}=$ Cons $\tan t+\beta_{\text {Variables Variables }}+\beta_{\text {Firm Controls }}$ Firm Controls $+\varepsilon_{i}$ Dependent variable is dichotomous pulse dummy taking value 1 if firm's bank was same as lead manager and 0 otherwise.

Characteristic, Firm and Legal control variables are defined in Table 4.

\begin{tabular}{|c|c|c|}
\hline Independent Variables & $\begin{array}{l}\text { Dependent Variables } \\
\text { CEO equals Chairman } \\
\text { Model } 13\end{array}$ & $\begin{array}{l}\text { Committee(s) } \\
\text { Model } 14\end{array}$ \\
\hline Intercept & $-6.875(6.92)$ & $6.113(7.61)$ \\
\hline \multicolumn{3}{|l|}{ Characteristics } \\
\hline CEO equals Founder & $-2.202(1.71)^{*}$ & $-3.721(1.74)^{* *}$ \\
\hline Board Size & $0.373(0.39)$ & $0.140(0.29)$ \\
\hline Board Independence & $0.007(0.03)$ & $-0.106(0.06)^{* *}$ \\
\hline \multicolumn{3}{|l|}{ Firm Controls } \\
\hline Log Tangible Assets & $1.116(1.33)$ & $0.752(0.72)$ \\
\hline Log Revenue & $-0.078(1.20)$ & $0.171(0.90)$ \\
\hline Total Debt/ Total Assets & $0.466(2.65)$ & $-4.097(3.10)^{*}$ \\
\hline Observations & 30 & 30 \\
\hline Obs. with Dep $=0$ & 3 & 6 \\
\hline Obs. with Dep=1 & 27 & 24 \\
\hline LR statistic & 6.761 & 13.377 \\
\hline Probability (LR statistic) & 0.343 & 0.037 \\
\hline McFadden R-squared & 0.3466 & 0.4455 \\
\hline
\end{tabular}

Notes: $\quad(1){ }^{*} \mathrm{p}<0.10 ; * * \mathrm{p}<0.05 ; \dagger \mathrm{p}<0.01 ; \dagger \dagger \mathrm{p}<0.005$. Standard errors are in parentheses

(2) White cross-section standard errors \& covariance (d.f. corrected) 
Table 8. Characteristics of and effects of CEO and Director-shareholder ownership in West African IPO firms

This table presents the results from OLS regression analysis of determinants of block-shareholding in West African IPO Firms in panel 1:

Ownership $_{i}=\beta_{\text {Characteristics }}$ Characteristics $+\beta_{\text {Firm }}$ Firm Controls Ch $_{i}+\beta_{\text {IPO Variables }}$ IPO Variables Var $_{i}+\varepsilon_{i}$ and the two stage least squares regression into the effects of director-ownership on underpricing ( 2 weeks) in panel 2. Characteristic variables, Firm and IPO controls are defined in Table 4 . Instrument variables used in 2SLS are Underwriter is Foreign and Founder o Board, which is dichotomous taking value 1 if condition is satisfied and 0 otherwise.

\begin{tabular}{|c|c|c|c|c|}
\hline & Panel 1 & & & Panel 2 \\
\hline & OLS & OLS & & $2 \mathrm{SLS}$ \\
\hline Dependent Variables & CEO-shareholding (\%) & Director-shareholding (\%) & Dependent Variables & Underpricing ( 2 weeks) \\
\hline Independent Variables & Model 15 & Model 16 & Independent Variables & Model 17 \\
\hline Intercept & $59.009(22.09) \dagger$ & $-5.954(44.20)$ & Intercept & $-167.803(59.28) \dagger$ \\
\hline Characteristics & & & Characteristics & \\
\hline CEO equals Chairman & $-46.002(7.39) \dagger \dagger$ & $-53.201(15.18) \dagger \dagger$ & Director ownership (\%) & $0.579(0.32)^{* *}$ \\
\hline Committee (s) & $4.561(5.56)$ & $19.913(11.47)^{* *}$ & & \\
\hline CEO equals Founder & $17.373(4.99) \dagger \dagger$ & $23.130(9.96) \dagger \dagger$ & & \\
\hline Board Size & $-1.631(0.80)^{* *}$ & $0.064(1.64)$ & & \\
\hline Legal Controls & & & Legal Controls & \\
\hline Legal Origin & $-1.258(4.84)$ & $-22.829(9.70) \dagger \dagger$ & Legal Origin & $7.215(16.62)$ \\
\hline Log Contract Enforcement & $-5.636(10.39)$ & $18.648(20.35)$ & Log Contract Enforcement & $71.115(30.24) \dagger$ \\
\hline Firm Controls & & & Firm Controls & \\
\hline Log Tangible Assets & $2.583(2.53)$ & $1.912(4.98)$ & Log Tangible Assets & $-8.978(7.99)$ \\
\hline Log Revenue & $-0.348(2.03)$ & $1.289(4.13)$ & Log Revenue & $3.407(4.43)$ \\
\hline Total Debt/ Total Assets & $-3.353(6.07)$ & $-20.389(12.54)^{* *}$ & Total Debt/ Total Assets & $14.825(16.44)$ \\
\hline Fixed Effects & No & No & Fixed Effects & No \\
\hline Observations & 29 & 30 & Observations & 18 \\
\hline F probability & 12.080 & 5.105 & F probability & 2.216 \\
\hline F-test all coefficients $=0$ & 0.000 & 0.001 & F-test all coefficients $=0$ & 0.119 \\
\hline Adjusted R2 & 0.7807 & 0.5602 & Adjusted R2 & 0.2067 \\
\hline
\end{tabular}

Notes: $\quad(1) * \mathrm{p}<0.10 ; * * \mathrm{p}<0.05 ; \dagger \mathrm{p}<0.01 ; \dagger \dagger \mathrm{p}<0.005$. Standard errors are in parentheses

(2) White cross-section standard errors \& covariance (d.f. corrected) 
Figure 1. Underpricing (2 weeks) versus Director ownership

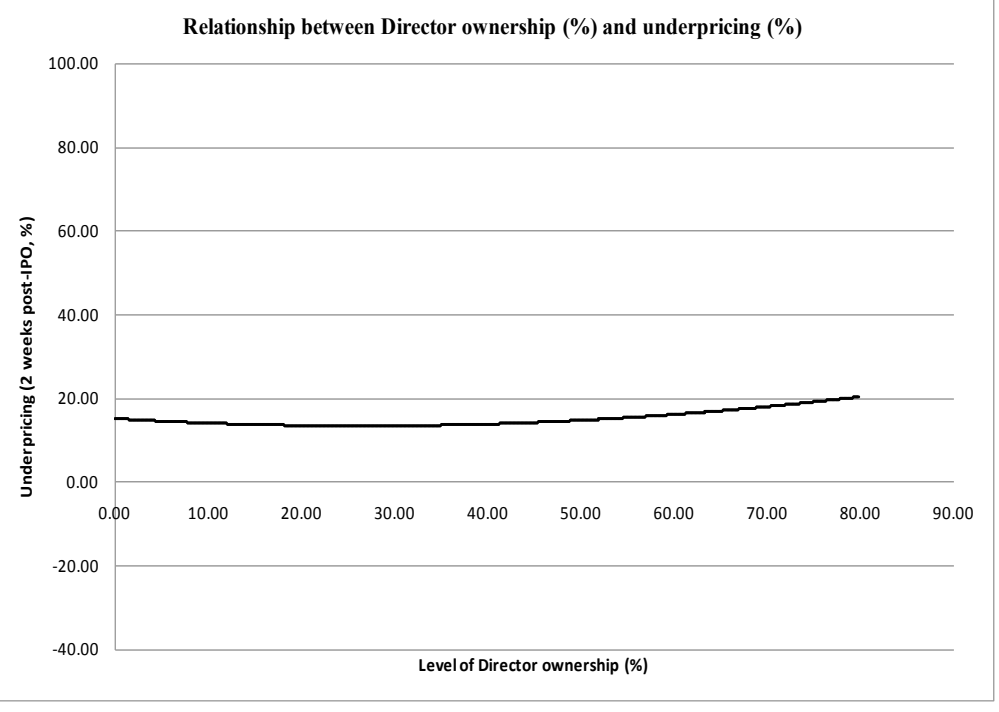

Figure 2. Underpricing (2 weeks) versus Founder ownership

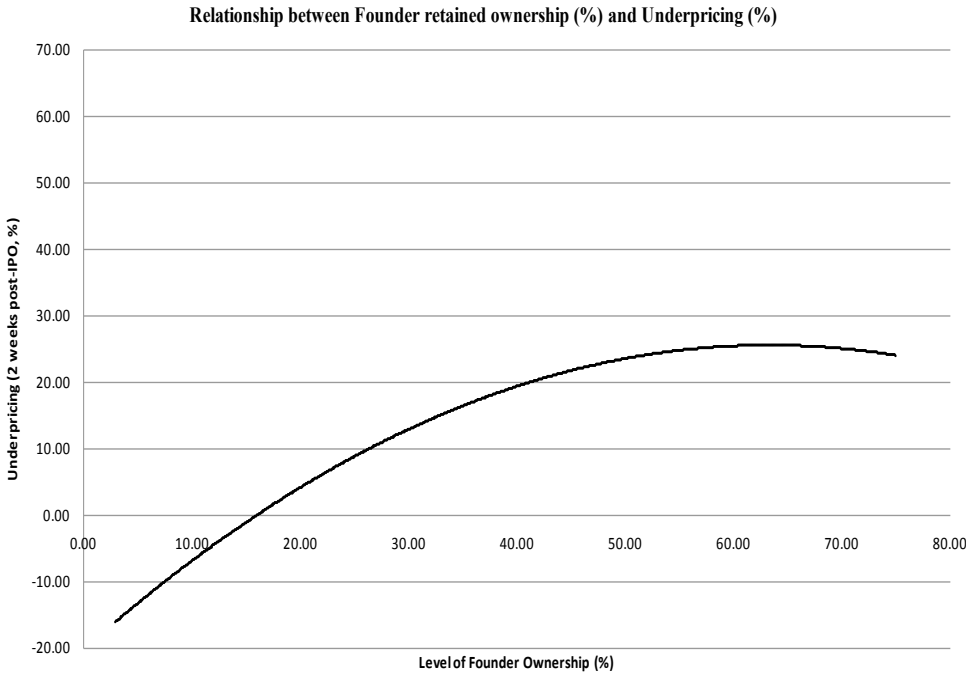

